\title{
Agency for Healthcare Research and Quality (AHRQ) Webinar Features 3 Journal of American Board of Family Medicine Practice-based Research (PBR) Articles
}

\author{
Phillip Lupo Jr., MLIS, Anne Victoria Neale, PhD, MPH, and \\ Marjorie A. Bowman, MD, MPA
}

In March 2015 the Practice-based Research Network (PBRN) Resource Center of the Agency for Healthcare Research and Quality hosted a special webinar featuring 3 articles from the 2014 fournal of the American Board of Family Medicine ( $7 A B F M)$ special practice-based research issue. Moderated by Rebecca Roper, MS, MPH, Director of the Agency for Healthcare Research and Quality PBRN Initiative, the webinar featured Drs. Larry A. Green, MD, from the University of Colorado, Denver; James J. Werner, PhD, from Case Western Reserve University; and Rebecca S. Etz, PhD, from the Virginia Commonwealth University Medical Center, who presented research based on their FABFM publications. ${ }^{1-3}$ The discussion focused on ways in which PBRNs may improve their infrastructure, aptitude, workforce, and reputation through a variety of learning opportunities both within individual PBRNs and across PBRN consortia.

The recorded webinar can be accessed at http:// pbrn.ahrq.gov/events/contextual-relevancy-andresearch-collaborations-pbrns-foster-partnershipspragmatic-prompt.

Conflict of interest: The authors are editors and staff of the 7ABFM.
In addition, links to each of the $7 A B F M$ articles discussed in the webinar can be accessed from the FABFM website:

1. Etz RS, Hahn KA, Gonzalez MM, Crabtree BF, Stange KC. Practice-based innovations: more relevant and transportable than NIH-funded studies. ${ }^{1}$ Available from: http://jabfm.org/content/27/ 6/738.full.

2. Green LA. Who will establish a proper data model for family medicine and primary care ${ }^{2}$ Available from: http://jabfm.org/content/27/6/ 736.full.

3. Werner JJ, Stange KC. Praxis-based research networks: an emerging paradigm for research that is rigorous, relevant, and inclusive. ${ }^{3}$ Available from: http://jabfm.org/content/27/6/730.full.

\section{References}

1. Etz RS, Hahn KA, Gonzalez MM, Crabtree BF, Stange KC. Practice-based innovations: more relevant and transportable than NIH-funded studies. J Am Board Fam Med 2014;27:738-9.

2. Green LA. Who will establish a proper data model for family medicine and primary care? J Am Board Fam Med 2014;27:736-7.

3. Werner JJ, Stange KC. Praxis-based research networks: an emerging paradigm for research that is rigorous, relevant, and inclusive. J Am Board Fam Med 2014;27:730-5.

doi: $10.3122 /$ jabfm.2015.04.150160 